\title{
Reforming Capital Taxation in Italy
}


Reforming Capital Taxation in Italy

\author{
Luc Eyraud
}




\title{
IMF Working Paper
}

Fiscal Affairs Department

\section{Reforming Capital Taxation in Italy ${ }^{1}$}

Prepared by Luc Eyraud

Authorized for distribution by Julio Escolano (FAD) and Kenneth Kang (EUR)

January 2014

\section{This Working Paper should not be reported as representing the views of the IMF.} The views expressed in this Working Paper are those of the author(s) and do not necessarily represent those of the IMF or IMF policy. Working Papers describe research in progress by the author(s) and are published to elicit comments and to further debate.

\begin{abstract}
This paper reviews capital taxation issues in Italy based on a comprehensive definition encompassing taxes on income, transactions, and ownership. It discusses options to enhance the neutrality of the capital income tax system, followed by a detailed analysis of the property tax, the inheritance tax, and various transaction taxes. The paper also examines the case for replacing the set of existing taxes on financial and real assets with a single net wealth tax.
\end{abstract}

JEL Classification Numbers: H2, H21, H31

Keywords: Capital taxation, tax efficiency, redistribution, wealth

Author's E-Mail Address: leyraud@imf.org

\footnotetext{
${ }^{1}$ This paper, which relies on and develops the findings of IMF (2012) has benefited from comments and inputs received from Ruud de Mooij, Kenneth Kang, Michael Keen, Thornton Matheson, John Norregaard, Justin Tyson, and Lawrence Walters. The author would also like to thank the staffs of the Italian Ministry of Economy and Finance and the Bank of Italy for helpful discussions and suggestions. Maria Delariarte, Amara Myaing, and Ted Twinting provided editorial help.
} 


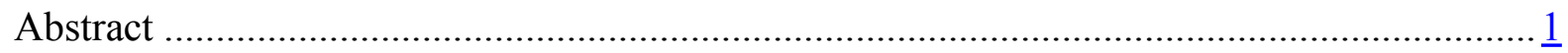

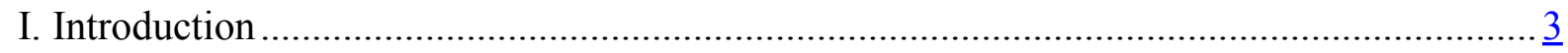

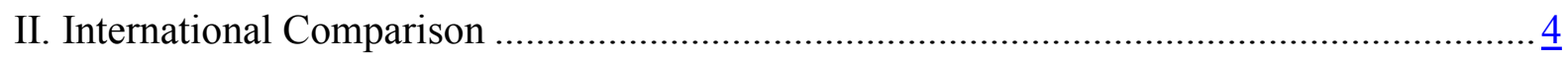

III. Enhancing the Neutrality of the Capital Income Tax System ..............................................

IV. Implementing a Fairer and More Effective Property Tax .................................................. $\underline{8}$

V. Reducing Distortionary Taxes on Transactions …………………................................

VI. Strengthening the Taxation of Inheritance and Gifts ..................................................... 14

VII. Towards a More Comprehensive Taxation of Wealth? ……………………………..... 18

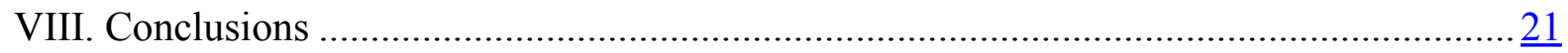

Tables

1. Capital Tax Measures in the 2011 Fiscal Packages ............................................................. 4

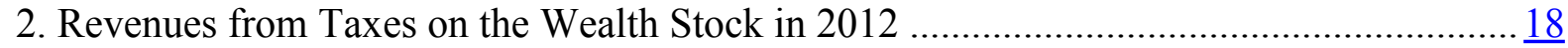

3. Composition of Italian Household Wealth per Net Wealth Decile ...................................... 19

Figures

1. Capital Taxation in European Countries, 2011 ............................................................ $\frac{5}{5}$

2. Taxes on Wealth Stock and Transactions in the OECD, 2011 …..................................... $\frac{5}{2}$

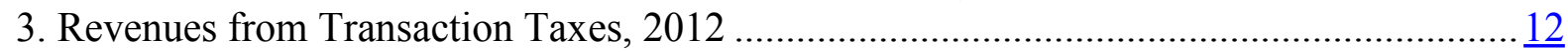

4. Residential Mobility in OECD Countries ……….....................................................

5. Effective Inheritance Tax Rates in Europe................................................................ 16

Boxes

1. Taxes on Asset Holding in Italy .............................................................................

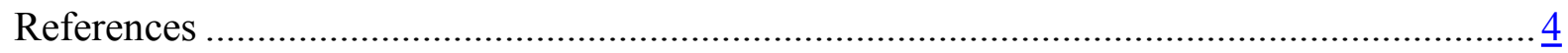




\section{INTRODUCTION}

This paper explores different dimensions of the capital taxation system in Italy, based on a comprehensive definition encompassing taxes on: (i) capital income (business profit, dividends and interest received by individuals, capital gains, and rent); (ii) capital transfer (inheritance and transaction taxes); and (ii) capital stock (property and net wealth taxes). ${ }^{1}$ The analysis is not exhaustive, however, and focuses on selected issues of current interest. Some important aspects beyond the scope of this paper are deliberately omitted; in particular, the regional production tax, which is not specifically a tax on capital.

Reforming capital taxation is of considerable practical importance and current interest in Italy. The 2011 consolidation packages relied largely on increased taxation of some transactions and items of capital income and of wealth. About one-fifth of the summer packages and half of the December package relied on capital taxation (Table 1), in particular the reintroduction of the primary residence tax in the December manovra of the Monti government. The capital tax structure was not significantly modified in 2012, although a financial transaction tax (FTT) was adopted at the end of the year, taking effect from March 2013. The property taxation framework was again modified by the 2014 Stability Law which repealed the tax on primary residences and the waste disposal tax, and replaced them with local service taxes effective from $2014 .^{2}$

In addition, the authorities have prepared a framework law setting out the strategic directions for a targeted tax reform (IMF, 2012). This frame law is referred to as "Delega fiscale" (DF) as the government plans to use "delegated legislation" to conduct the tax reform - that is, Parliament passes a law outlining general principles, which also authorizes the government to proceed in legislating the actual details with decrees. The authorities' plan is to adopt the DF at the beginning of 2014 .

Sustaining and expanding these recent reforms could significantly strengthen the design of the tax system. In particular, further progress towards a dual income tax system would enhance the coherence and effectiveness of the income tax structure. Unifying the tax treatment of retained earnings across different types of business could ease the distortions of business decisions. Updating cadastral values is essential for greater fairness in property taxation, and could finance a reduction in the property tax rates - and more importantly a cut in property transaction taxes. Consideration could also be given to an explicit wealth tax and/or a strengthening of inheritance taxes, which could create space to lower taxes on capital and labor income.

\footnotetext{
${ }^{1}$ In terms of their economic impact, the classification of various taxes considered in this paper is not always clear cut. For instance, the fixed charge on bank account introduced in December 2011 is not really a tax on a specific transaction nor, since it is unrelated to the balance of the account, is it a tax on wealth.

${ }^{2}$ The property tax on secondary homes and non-residential properties was not affected.
} 


\section{Table 1. Capital Tax Measures in the 2011 Fiscal Packages ${ }^{1}$}

\begin{tabular}{|c|c|c|c|}
\hline \multicolumn{2}{|c|}{ July-September Packages (in billions of Euros) } & \multicolumn{2}{|c|}{ December Package (in billions of Euros) } \\
\hline Stamp duty on securities accounts & 1.3 & $\begin{array}{l}\text { First house property tax and base } \\
\text { re-evaluation }\end{array}$ & 10.7 \\
\hline Higher IRAP on banks ${ }^{2}$ & 1.0 & Luxury good tax & 0.4 \\
\hline Capital income taxation ${ }^{3}$ & 1.4 & $\begin{array}{l}\text { Stamp duty (including on financial } \\
\text { instruments) }\end{array}$ & 1.2 \\
\hline \multirow[t]{3}{*}{ Income surtax for energy sector } & 1.8 & Tax on real assets held abroad & 0.1 \\
\hline & & IRAP deductibility 2,4 & -1.5 \\
\hline & & Allowance for corporate equity & -1.0 \\
\hline Total & 5.5 & Total & 9.9 \\
\hline In percent of total 2012 package & $19 \%$ & In percent of total 2012 package & $49 \%$ \\
\hline \multicolumn{4}{|c|}{$\begin{array}{l}\text { Source: Italian authorities' projections. } \\
1 \text { Simulated impact on } 2012 \text { revenues. } \\
2 \text { The IRAP bears on capital and labor; the two components cannot be separated. } \\
3 \text { The withholding tax on interest (except government bonds) and dividends was unified at } 20 \text { percent. } \\
4 \text { Deductibility of IRAP from CIT. }\end{array}$} \\
\hline
\end{tabular}

To further examine these issues, the paper is organized as follows. Section II provides some elements of international comparison. Section III assesses the taxes on capital income through the prism of neutrality. Section IV analyzes the real estate tax with an emphasis on properties' valuation. Taxes on wealth transfers are discussed in Section V (transaction taxes) and Section VI (inheritance and gift taxes). Section VII raises the broader question of whether a comprehensive wealth tax could be warranted as a substitute for existing taxes. Section VIII concludes.

\section{INTERNATIONAL COMPARISON}

Italy's capital taxation is comparatively high. According to Eurostat, capital taxes ${ }^{3}$ in Italy yielded 10 percent of GDP, the fourth highest revenue in the EU-27 in 2011 (Figure 1). This result partly reflects the methodology used by Eurostat, which books all taxes and social contributions paid by the self-employed, a large group in Italy, as capital income taxes (instead of splitting them between capital and labor). Nonetheless, other capital taxes are also above average, with taxes on household income, capital stock, and corporate income ranking respectively 5 th, 6 th, and 9 th in the EU. The implicit tax rate on capital ${ }^{4}$ is also very high at 33.6 percent, as well as the share of capital taxes in total taxes (23.5 percent).

\footnotetext{
${ }^{3}$ Eurostat breaks down general government taxes by type of tax base — capital, labor and consumption. Some taxes (such as the Regional tax on Productive Activities, IRAP) are split between labor and capital. The "capital tax" category includes taxes on business income in a broad sense (not only taxes on profits but also taxes and levies that could be regarded as a prerequisite for earning profit) and taxes on capital stocks of households or their transaction.

${ }^{4}$ The implicit rate is the ratio of revenues to the potential tax base.
} 


\section{Figure 1. Capital Taxation in European Countries, 2011}

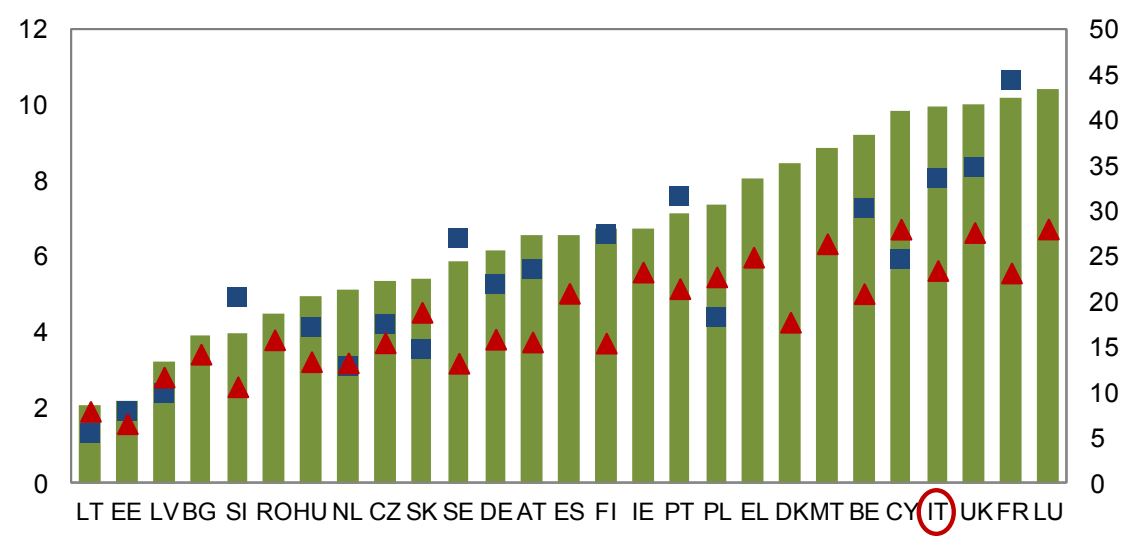

Source: Eurostat

Taxes on capital, in percent of GDP (Ihs)

- Implicit capital tax rate, in percent (rhs)

Share of capital tax revenue in total taxes, in percent (rhs)

In terms of structure, Italy's reliance on transaction taxes stands out, with taxes on financial and capital transactions amounting to about half of total taxes on wealth in 2011 -compared to one fourth for the OECD average (Figure 2). ${ }^{5}$ The reform of the real estate tax increased immovable property revenues from 0.7 percent of GDP in 2011 to 1.5 percent in 2012 -above the OECD average (1.1 percent) but still significantly below taxes raised in Japan (2.2 percent of GDP), France (2.5 percent), the US (3.1 percent), and the UK (3.3 percent).

Figure 2. Taxes on Capital Stock and Transfers in the OECD, 2011 (Percent of GDP)

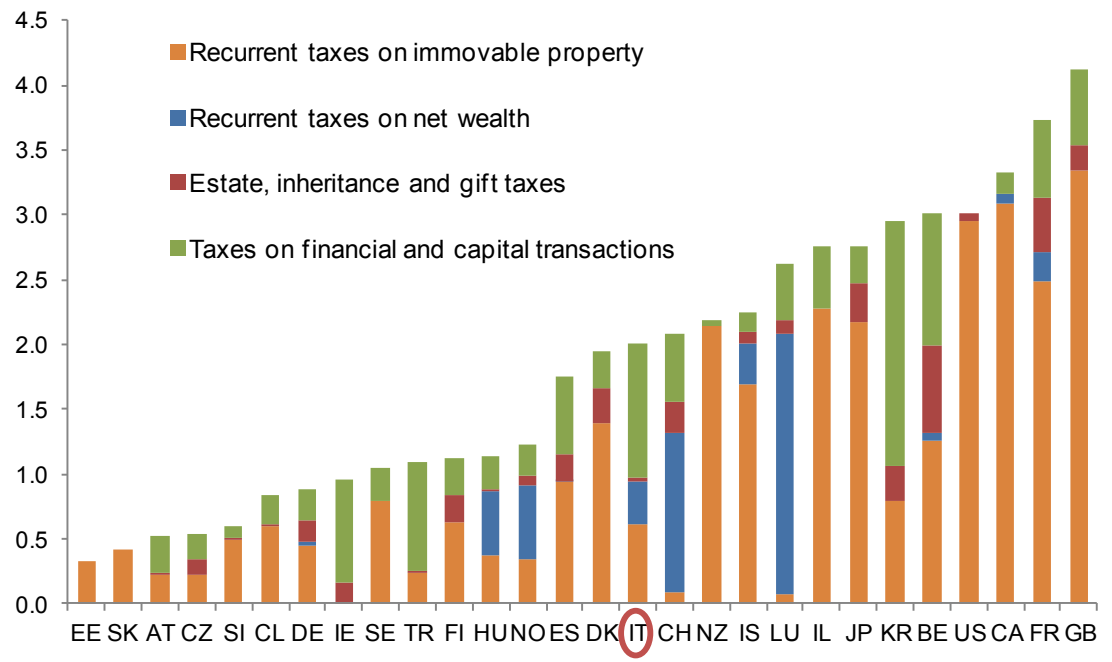

Source: OECD Revenue Statistics.

Note: Taxes on capital stock and transfers are a subset of capital taxes; see introduction.

\footnotetext{
${ }^{5}$ At the time of writing this paper, data for 2012 were not available in the OECD revenue statistics database. However, the increase in the property tax is likely to have mechanically reduced the reliance on transaction taxes.
} 


\section{Enhancing The Neutrality of The CAPITAl Income Tax SySTEM}

The essence of a dual income tax (DIT) is to tax capital income at a low single rate and labor income under a progressive schedule. The DIT differs from a "comprehensive" income tax in distinguishing between capital and labor income (rather than subjecting the sum of the two to a single progressive scale) and from an "expenditure" tax in that it taxes the return to capital. Pioneered in Nordic countries, the DIT has several merits (Boadway, 2004). Perhaps most compelling, the increased international mobility of financial capital makes it increasingly difficult to tax capital income at rates as high as the marginal rates felt appropriate for labor taxation. ${ }^{6}$

One essential benefit of the DIT is that it minimizes the distortions created by the multiplicity and diversity of capital income taxes. Under the DIT, all forms of capital income are taxed at the proportional profit tax rate. By providing a level playing field for owners of different forms of capital income, there would be no tax incentive arbitrage among dividends, interest, rents, rental values, royalties, and capital gains. In addition, to avoid arbitrage opportunities and facilitate implementation, the textbook prescription is to set the corporate profit tax rate equal to the single rate on capital income. ${ }^{7}$ Finally, the double taxation of distributed profits at the corporate level and the shareholder level is avoided, under a pure DIT, through a full imputation system. ${ }^{8}$

The Italy tax system has evolved towards a DIT, providing a coherent and practicable framework for strengthening tax design. Several features of the Italian tax system have DIT features, including the single and very similar rates applied to rental income ( 21 percent); interest income other than from government debt (20 percent); dividends not associated with a "qualified" (i.e., substantial) shareholding (20 percent or more); and capital gains on most financial instruments (20 percent). The unification of withholding rates on interest income was one of the key measures of the August 2011 fiscal package.

Adoption of the Allowance for Corporate Equity has also been an important step towards the DIT system in Italy. Tax systems generally favor corporate debt over equity, because interest payments are deductible for corporate income tax purposes, while equity returns are not (De Mooij, 2011). The introduction in December 2011 of an Allowance for Corporate Equity (Aiuto alla Crescita Economica; ACE) has eased the tax bias toward debt finance and made equity

\footnotetext{
${ }^{6}$ The DIT has also potential drawbacks, including the need to distinguish capital from labor income-when small businesses can readily shift between the two-and the perception of inequity in charging a lower tax rate on those, likely to be among the better off and more heavily dependent on capital income.

${ }^{7}$ If the corporate tax rate exceeds the flat tax on interest income, for instance, there is a tax gain from lending to corporations.

${ }^{8}$ This result is partly achieved by an allowance for corporate equity, which eliminates the double taxation of normal equity returns (but not that of normal profits). See discussion below.
} 
injections more attractive, by providing a tax deduction to companies for a notional return on additional equity. ${ }^{9}$ It thus neutralizes the preferential tax treatment of debt finance, which was present under the old system. These are very attractive properties: the importance of avoiding tax incentives to artificially high leverage, especially but not only for financial institutions, has emerged clearly since 2008. Given to the positive experience of several countries with ACE or similar systems, many now advocate widespread adoption of the ACE (IMF, 2010; Klemm, 2007; Mirrlees and others, 2011).

There remain some differences from the textbook DIT in Italy. These include the taxation of (half of) dividends under progressive personal income tax (Imposta sul Reddito delle Persone Fisiche IRPEF) rates for qualified shareholdings, the potential taxation of capital gains on real estate at the IRPEF rate ${ }^{10}$, and the absence of any attempt to apply differential taxation of labor and capital income to unincorporated businesses. Notable too is that distributed corporate earnings (in excess of a normal rate of return) are taxed at effective rates that are close to the top marginal IRPEF rate (43 percent) rather than the rate on interest income ( 20 percent). ${ }^{11}$ Finally, the IRES rate (27.5 percent) is also clearly above the interest income rate.

Present tax arrangements are not neutral, however, between different organizational forms. This may create distortions of business decisions regarding incorporation. A first concern is that retained profit of a corporation is subject to IRES, while business income of partnerships and sole proprietorships is liable for IRPEF, which is generally levied at a higher marginal tax rate, at least for high incomes (the range of IRPEF progressive rates is 23-43 percent, while the IRES flat rate is 27.5 percent). This may lead to tax-motivated incorporation. In addition, the profit of a corporation is liable for tax at personal level only if the profit is distributed; corporations can thus postpone personal tax payment by deferring realization. Partnerships and sole proprietorships do not have this option as their entire income is subject to IRPEF. On the other hand, to the extent that income is distributed, these groups are generally tax favored, since the progressive IRPEF rate is typically below the effective tax rate imposed on dividends distributed

\footnotetext{
${ }^{9}$ For the first three fiscal years (2011-13), the notional interest rate was set at 3 percent. It will increase in subsequent years (4\% in 2014, 4.5\% in 2015, and 4.75\% in 2016 according to the 2014 Stability Law). Thus, with the ACE, normal equity returns are fully deductible and taxed only at a personal level, while returns above that are still taxed at both the corporate and the individual level.

${ }^{10}$ No taxation is applied if the property has been held for at least 5 years or if it has been used as primary residence.

${ }^{11}$ While distributions by non-corporate entities are simply taxed under the progressive IRPEF, corporate distributions are subject to two layers of taxation, at the corporate and personal levels. Specifically, the effective tax on distributed corporate earnings is a combination of (i) the corporate income tax (Imposta sul Reddito delle Società, IRES) levied at a 27.5 rate, and (ii) the dividend tax, which is either levied at 20 percent for non-qualified shareholdings or at progressive IRPEF rates on half of the dividends received for qualified shareholdings. Therefore, the effective tax rate is 42 percent $(=(0.275)+(0.2) \times(1-0.275))$ for non-qualified shareholdings; it is 43 percent $(=0.275+(0.43) \times(0.5) \times(1-0.275)$ for a qualified shareholder paying IRPEF at the top marginal rate of 43 percent.
} 
by corporations. ${ }^{12}$ This creates a disincentive to incorporation for businesses with low incomes. Moreover, the ACE itself is particularly beneficial for partnerships and sole proprietorships, both because the notional return to equity is then deducted at a higher rate (at least for those with reasonably high incomes ${ }^{13}$ ) and because they enjoy the allowance with respect to all equity, whereas corporations receive it only in respect of equity built up since the introduction of the ACE.

To address these issues, the authorities are considering unifying the tax treatment of retained earnings across different types of businesses. The DF proposes to introduce a new business tax (irrespective of the legal form) dubbed Imposta sul Reddito Imprenditoriale (IRI). The IRI would be levied on retained earnings at the same rate as the IRES; all outflows to owners or managers would be deductible but fully taxable at personal level under the IRPEF. Firms liable to IRI would thus be taxed exactly like corporations with respect to their retained earnings; and the difference in respect of distributions would be quite small. ${ }^{14}$ The reform would thus bring greater neutrality between corporations taxed under the IRES and other entities (including small businesses) taxed under the IRI. This would be an important move toward a business-neutral tax for entrepreneurs.

Making the IRI optional, as envisioned by the DF, may nonetheless complicate the tax system and run significant budgetary risk. Optionality is obviously attractive for business: they could, and presumably would, all else equal, opt for whichever regime offers them the lowest tax liability. The converse is of course a risk to government's revenue. Moreover, options can tend to significantly complicate the tax administration, increasing both administration and compliance costs. If a compulsory regime would be too burdensome for some companies in the short term, optionality might be considered during a short transitional period. But ultimately, there should ideally be a single regime for all businesses other than the smallest enterprises. Determining the set of companies for which the IRI is to be mandatory would be a critical element in the final design of the reform.

\section{Implementing a Fairer and More Effective Property TaX}

Immovable property taxes now yield fairly modest amounts in most countries, while there are strong economic arguments for strengthening them (Norregaard, 2013). Property taxes in the

\footnotetext{
${ }^{12}$ More specifically, the top marginal rate of the progressive IRPEF (43 percent) - which is an upper limit to the average rate-is either exactly equal to (for qualified shareholdings) or one percentage point above (for nonqualified shareholdings) the effective average rate implied by the combination of the IRES and dividend taxation . See calculations in previous footnote.

${ }^{13}$ By definition, the higher the marginal tax rate, the higher the deduction.

${ }^{14}$ Indeed, as shown above, the gap between the IRPEF rate and the combined rates of IRES and dividend tax is small at higher income levels.
} 
form of recurrent taxes levied on land and buildings are generally considered to be more efficient than other taxes with a less adverse impact on the allocation of resources, primarily because their tax base is less mobile. Studies on the growth hierarchy of taxes have generally found taxation of immovable property to be more benign for economic growth than other forms of taxation, in particular compared to direct taxes (Arnold and others, 2011). These efficiency properties are enhanced when the tax - mainly borne by residents - functions as a "benefit tax" 15 that finances local government services: if perceived as payment for services, the tax should be fully neutral with respect to labor supply, investment and savings decisions. In addition, to the extent that increases in property taxes are fully capitalized in property prices, with resulting oneoff losses for present owners, the tax increase should not affect the rate of return for new owners and could therefore be neutral to investment behavior. Finally, property taxes are considered a relatively stable revenue source and - by requiring little international tax coordinationattractive to economies that are otherwise exposed to tax competition for mobile tax bases. ${ }^{16}$

While taxes on property in Italy are not low, they are not out of line with other advanced economies. The introduction of the Imposta Municipale (IMU) at the start of 2012 fundamentally reformed, and increased, property taxation. In replacing the previous Imposta Comunale sugli Immobili (ICI), it brought primary residences back into the tax base and scaled up cadastral values by adjusting them with ad hoc factors. Property tax revenue more than doubled in 2012 to 1.5 percent of GDP.

As part of the implementation of the IMU, cadastral values were adjusted by a common factor within each property type. The current property valuation system is based on estimates of market rental values from 1988-89, and so is out of date. The basis for both the old ICI and the current IMU is the concept of cadastral rental value. This is an estimate of what the "normal" (i.e., average for similar properties in the same general location) rental value of the subject property would be as of 1988-89. It is based on location and building type, but very little else; there is, for instance, no information on type of construction, building condition, or even age of building. As part of the IMU reform, an ad hoc increase in property values was implemented through the application of multiplicative factors to the tax base. The revaluation coefficient for houses was 1.6; for other types of properties, reevaluation ranged from 1.2 to 1.6 percent. These factors resulted in a significant increase in taxable value by about 50 percent overall.

However, the application of common factors has not fully addressed the issues of the property tax system. First, despite the revaluation, the taxable values of many properties remain well below market value. The national average ratio of market to taxable value is still 2.2 for primary residences and 2.4 for other dwellings. Second, property values have increased markedly in the

\footnotetext{
${ }^{15}$ The "benefit principle" of taxation taxes people in proportion to the marginal benefits they receive from government goods and services.

${ }^{16}$ A steep increase in property taxation may, nonetheless, affect negatively the real estate market and reduce liquidity (and consequently consumption) of landlords.
} 
last 20 years, but not uniformly throughout the country. Changes in property values would not be problematic if all changes were proportionate and uniform across the country: tax rates could simply be adjusted or a common valuation adjustment factor be applied to all properties. Unfortunately, this is not the case in Italy. Since 1988-89, real estate prices have increased five-fold in some regions, and by only half that in others, and there are similar variations within every major city in Italy. This asymmetry and variability across the country makes the current cadastre unfair and inefficient. Simple adjustment factors cannot overcome disparities in assessed values and cannot address equity concerns.

The update and reform of cadastral values are widely regarded as essential. There are many ways to conduct the revaluation of properties. Policy options can be arranged along a continuum, with market-driven approaches based on capital market value on one end, and non-market approaches based on purely physical property characteristics on the other (Walters, 2011). In Italy, the Revenue Agency (which has recently incorporated the Land Agency) could implement a "comparable sales approach" for properties regularly exchanged in the market. ${ }^{17}$ For more unique properties with a lack of comparative sales, individualized valuations are required, based either on a "cost-based approach" for owner-occupied properties or an "income approach" for income producing properties. ${ }^{18}$

The substantial increase in taxable values could finance a large reduction in IMU rates - and perhaps even more beneficially in transactions taxes. The taxable base for housing is still less than half the average market value nationally, so that comparable revenue at the national level could be raised after comprehensive revaluation with less than half the current tax rate. A strong case can be made for using some of this revenue increase to reduce distortionary taxes on transactions related to real property (see discussion in the following section).

The crucial task of maintaining the cadastre and cadastral values will require resources. Maintaining land and building records for over 83 million parcels and carrying out individualized appraisals for over one million specialized cadastral properties will strain the Revenue Agency. Some of the management tasks can be effectively shared with municipalities and other local agencies. But this too will require resources. And once updated, the cadastral values must be maintained and updated on a regular basis (for instance, every three years), otherwise the current valuation inaccuracies and inequities will quickly return. One approach that has proven effective in other countries is to dedicate a small portion of the property tax revenue for the maintenance of the assessment and collection system.

\footnotetext{
${ }^{17}$ The comparable sales approach consists in collecting data on recent sales of similar properties to estimate an average price per square meter for a given building type, based on building location and other characteristics.

18 The cost approach estimates what it would cost to reproduce or replace the property by calculating the price of each component (including improvements) and adjusting for obsolescence. The income approach is based on capitalizing the expected income flows from a property.
} 
One option for collecting additional required data is self-declaration by the taxpayer. It has proven feasible in other countries to require the taxpayer to complete an objective description of their property as part of the tax collection process (Walters, 2011). For sure, not all taxpayers will complete the additional form and some will submit erroneous data. The Revenue Agency will need an audit staff and strategies as well as procedures to verify samples of submitted data, with well-publicized appeals procedures and penalties for those who deliberately falsify data. But many taxpayers will submit reasonably accurate data - and self-reporting would considerably reduce the cost of gathering additional information. Such an approach would not be perfect or costless, but might provide a fruitful way to accelerate progress.

Finally, it is also important to review property tax exemptions, particularly those relating to agricultural land. Roughly 60 percent of the land in Italy is currently exempted from the property tax. ${ }^{19}$ Broadening the base of the property tax further could substantially reduce tax rates or enhance local revenues. This is not to say that all exemptions are unjustified. Rather, the argument is that all exemptions from the property tax merit careful review to assure that their objectives remain valid and that they are sufficiently effective, including relative to other policy instruments, in achieving them.

\section{REDUCING DISTORTIONARY TAXES ON TRANSACTIONS ${ }^{20}$}

Transaction taxes are relatively high in Italy. Transaction taxes were estimated at 1.0 percent of GDP in 2011, twice the OECD average of 0.5 percent (Figure 2). Registration fees, levied on a wide range of transactions involving deeds, account for about half of all revenue from transactions taxes (Figure 3). Registration fees are levied on sales of real property, financial assets, and businesses, but also on other transactions, such as rents. Tax due is either fixed or proportional to the value of the asset, with rates ranging from 0.5 to 15 percent depending on the type of asset. Sales of shares of limited liability companies (SRLs), for instance, are subject to the fixed registration tax.

\footnotetext{
${ }^{19}$ Agricultural land is exempted from property tax when there are hilly or mountainous. Under a law adopted in 1977, approximately two-thirds of Italy's municipalities qualify under the exemption provisions of this law. In addition, municipalities have the authority to grant specific exemptions for particular social groups such as the poor and aged. Finally, public facilities such as transport services, government property, places of public worship, cemeteries and family vaults, and clock towers are exempt. The result is that approximately 60 percent of Italy's property is exempted from the IMU.

${ }^{20}$ Here, "transaction taxes" refer to all taxes on asset transfers, excluding on gifts and inheritances. "Stamp duties", which refer to a duty levied on the issuance of official documents, are treated here as a subset of transaction taxes.
} 
Figure 3. Revenues from Transaction Taxes, $2012^{1}$

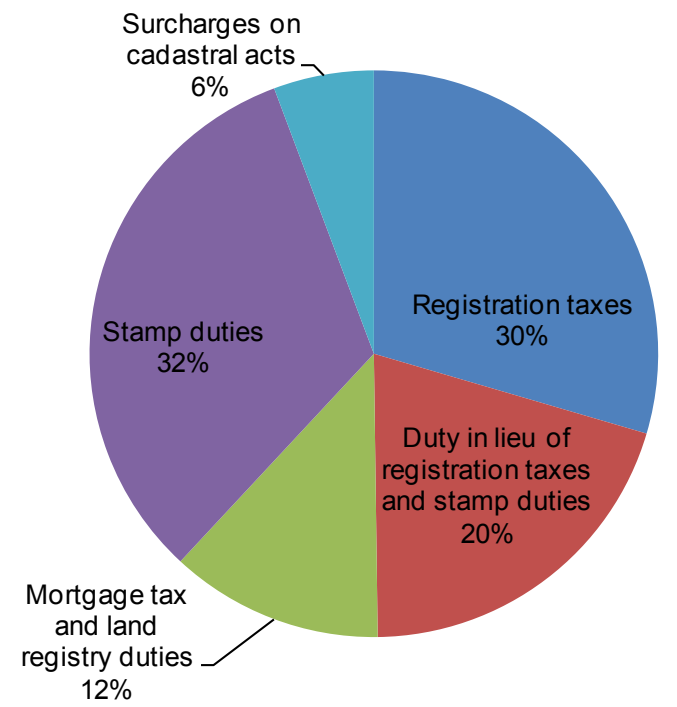

Source: ISTAT

${ }^{1}$ Excluding inheritance/gift tax

Transaction taxes bear heavily on immovable property. Transaction costs in the housing market are particularly high in Italy, about 25 percent above the OECD average (Andrews and others, 2011). Buyers must pay three taxes on their real estate purchase: the registration tax (imposta di registro), the mortgage tax (imposta ipotecaria), and the land registry tax (imposta catastale). The registration tax is levied on sales at rates ranging from 3-15 percent (depending on the type of property); for business assets, it is charged as a flat amount. The land registry tax is levied at 1 percent, while the mortgage tax rate is $2-3$ percent. ${ }^{21} \mathrm{VAT}$ is, in general, charged on new housing, at a rate of 4-22 percent depending on the property. If the sale is subject to VAT, the registration tax and land registry tax are reduced to a small flat amount (except for business assets).

Transactions taxes can be relatively easy to administer. Changes in ownership happen relatively infrequently and can be fairly easy for tax administrations to keep track of - especially when the purchaser has clear interest in ensuring that the necessary legal requirements reflecting the ownership change are completed (Thuronyi, 1996).

But they can also impose large efficiency costs. It might be argued that these taxes are user charges to finance the costs to the state of maintaining ownership records, and regulating transactions and asset markets. The revenue raised, however, may outweigh these costs. Most fundamentally they distort behavior, impeding mutually beneficial transactions and so hindering

\footnotetext{
${ }^{21}$ The base is in each case market value, not cadastral value, except for houses bought by individuals.
} 
the efficient allocation of assets (including by discouraging otherwise profitable investments that would increase the asset value).

Transaction taxes on real property may be particularly damaging. By discouraging transactions on the real estate market, they have far-reaching consequences. ${ }^{22}$ First, the reduced market liquidity may increase price volatility, although both theory and empirical evidence are mixed (transaction costs may also reduce volatility by curbing speculative transactions; Andrews, 2010). Second, transaction costs are likely to raise the elasticity of demand with respect to pretax prices, which may inflate housing prices and mitigate their response to supply shocks. ${ }^{23}$ Third, transaction costs create incentives for buyers and sellers to collude and partly evade the tax by arranging a lower price for the property and a corresponding separate payment, either informal or formal (for the fixtures and fittings) - this eases the distortions but undermines habits of tax compliance. Fourth - and perhaps most important - theoretical and empirical studies show that transaction costs create lock-in effects in the housing market and have negative effects on residential and job mobility, so impeding labor market matching and increasing structural unemployment (Oswald 1996, 1999; Van Ommeren and Van Leuvensteijn 2005; and Caldera Sánchez and Andrews 2011). Italy's residential mobility is indeed significantly below the OECD average - no doubt this reflects more than transactions taxes, but these clearly do not help (Figure 4).

There is a strong case for reducing transaction taxes on real property in Italy-perhaps using part of the revenue gains from an improved IMU to this end. In the context of the fiscal federalism reform, the authorities plan to substitute a single rate for most transaction taxes on immovable property from 2014. The Legislative Decree 23/2011 establishes the rates of this new tax at 2 percent for primary residences, and 9 percent on other properties, compared to the current rates which range between 3 and 18 percent. ${ }^{24}$ This effort to streamline transaction taxes should continue, and the order of magnitude of the rate cuts seems reasonable (although the reduction may still be on the low side for properties not used as primary residences). ${ }^{25}$ Further reform of the IMU including a review of the cadastre may provide an opportunity to do just this, by offsetting the increase in the IMU base by a cut in registration taxes.

\footnotetext{
${ }^{22}$ These effects are likely to be significant in Italy, since real estate transactions are also subject to relatively high notary fees (Andrews and others, 2011).

${ }^{23}$ This result holds under the assumption that supply and demand functions are linear and the tax is ad valorem.

${ }^{24}$ The exact coverage of the tax still needs to be specified and these provisions may be revised given that significant changes have been introduced to property taxation since the decree was adopted in March 2011.

${ }^{25}$ Under the assumption that half of transaction taxes bear on real property, the tax rates on real property transfers should be divided by four to reduce total transaction revenues to the OECD average.
} 
Figure 4. Residential Mobility in OECD Countries (Percentage of Households that Changed Residence within the Last Two Years)

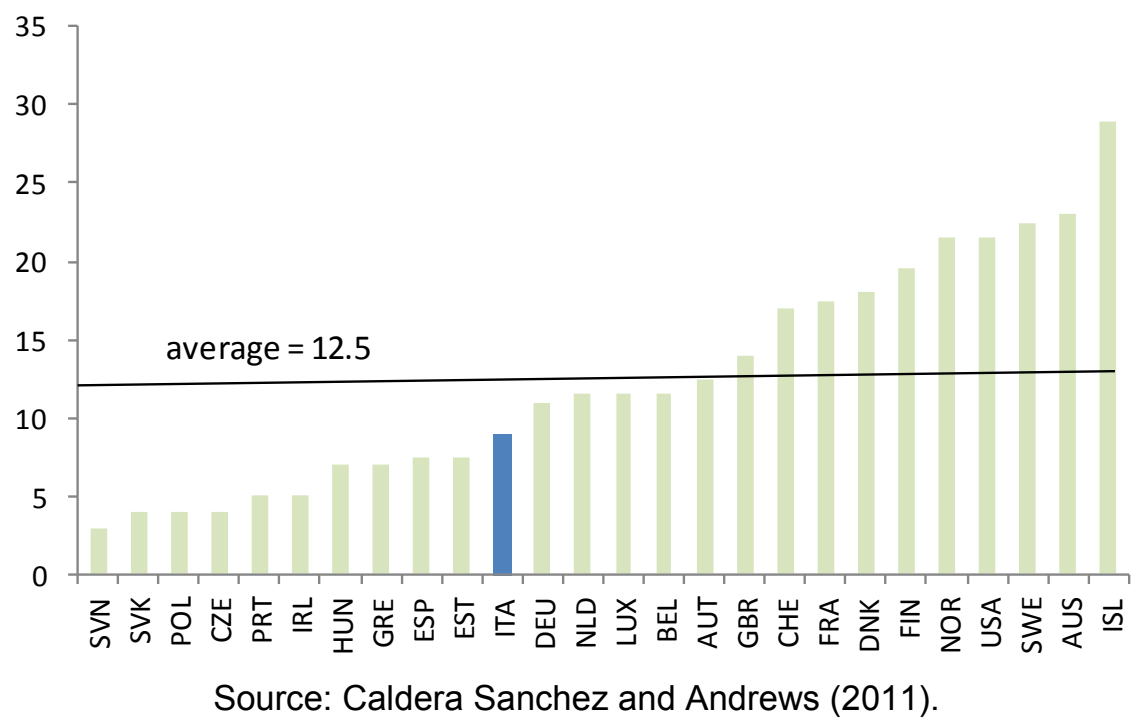

Italy has also recently adopted a FTT, ahead of the plan to introduce of a similar tax at the European level. With the financial crisis, FTTs have come under widespread scrutiny as a means to curb financial market excesses and raise revenue to meet the direct fiscal costs of future support to the financial sector (Matheson, 2012). In Italy, the FTT in effect since March 2013 targets three categories of transactions: transfers of equity instruments, equity derivative trades and high-frequency trading. Tax rates vary depending on the transaction type and whether it is executed on a regulated market or not. The FTT carries risks, as it may reduce trading volume and liquidity, and lower asset prices. ${ }^{26}$ In addition, it is unclear whether leverage will be discouraged, given the lower tax rate on derivatives, which are typically highly-leveraged transactions. There is also a risk of displacement of trading activities, as it may be difficult to enforce the tax outside of Italy. Finally, to the extent that the FTT taxes transactions between businesses, it can distort business decisions and reduce total output, so that more revenue could be raised by taxing that output directly. After reviewing several options, IMF (2010) has expressed a preference for a "Financial Activities Tax," levied on the sum of profits and remuneration of financial institutions, which would be broadly equivalent to a VAT for the financial sector. Overall, given the recent introduction of the Italian FTT, it would be wise to carefully monitor the effects of the tax on the stock markets, in order to evaluate its merits and drawbacks.

\section{STRENGTHENING THE TAXATION OF INHERITANCE AND GIFTS}

Italy taxes lifetime gifts and inheritances. Allowances are specified as lifetime amounts from a specific donor, and a running total must be kept if an individual receives more than one gift, or a

\footnotetext{
${ }^{26}$ The French FTT is found to reduce transaction volumes for most taxed stocks (Becchetti and others, 2013).
} 
gift and an inheritance from the same donor. Transfers are net of financial liabilities, and different rates and allowances apply according to the degree of kinship of the beneficiary. ${ }^{27}$ Transaction taxes are also due at death in some cases. ${ }^{28}$

The inheritance and gift tax currently raises little revenue. In 2012, it yielded $€ 520$ million, equivalent to 0.03 percent of GDP or 0.1 percent of total tax revenue. The main reason for this low yield is that the rates and allowances are quite generous (Figure 5). In France, allowances are significantly lower (each child benefit from a $€ 100,000$ allowance for instance), and marginal rates range from 5 to 60 percent. In Germany, the range of marginal rates is $7-50$ percent, while the child allowance is $€ 400,000$. In the U.K., the tax threshold for the whole estate is $£ 325,000$, and the tax rate is 40 percent. In Spain, marginal rates are between 7 and 34 percent, while the child allowance is up to $€ 47,859$. The asset valuation is another explanatory factor for the low yield of the tax: for real property gifts or bequests, the assessment base is the cadastral not the market value.

Structurally, the Italian inheritance and gift tax is well designed. It is close to a pure "doneebased" (or "accession") tax: each donee pays tax to the extent that wealth transfers received, whether by gift or inheritance, exceed a lifetime limit (Ireland being another example). This equalizes treatment between those who prefer to make lifetime gifts and those who keep their wealth until death, and eliminates some common gift-based avoidance schemes (where gifts, if made long enough before death, are taxed less heavily than inheritances). One weakness of current arrangements, however, from the perspective of equalizing treatment of beneficiaries, is that transfers from different donors are treated separately: so a donee is less heavily taxed if he or she receives a transfer from two different donors than if the transfer is made by only one donor (as allowances cumulate in the first case). The alternative - as for instance in Ireland - is to apply allowances to the sum of all prior gifts and inheritances received by a donee from different donors. Another practical weakness is that allowances thresholds are not automatically updated, but require a new ministerial decree. This has created problems of equity, liquidity, and public acceptability in other countries, as rising house prices have brought more and more of the middle classes into the inheritance tax. Some automatic adjustment for inflation could partly address this issue.

\footnotetext{
${ }^{27}$ The share of the estate received by the donee is taxed at 4 percent if the transfer is to a spouse or direct descendent or ancestor, with a tax allowance of $€ 1$ million; 6 percent if the transfer is to siblings, with an allowance of $€ 100,000 ; 6$ percent if the transfer is to other relatives, without any tax deduction; and 8 percent in all other cases.

${ }^{28}$ In the case of a real property transfer (by inheritance or gift), the donee has also to pay the mortgage tax and the land register tax ( 3 percent of the cadastral value of the property). If the property is registered as the donee's principal residence, both taxes are reduced to a small flat fee.
} 


\section{Figure 5. Effective Inheritance Tax Rates in Europe}

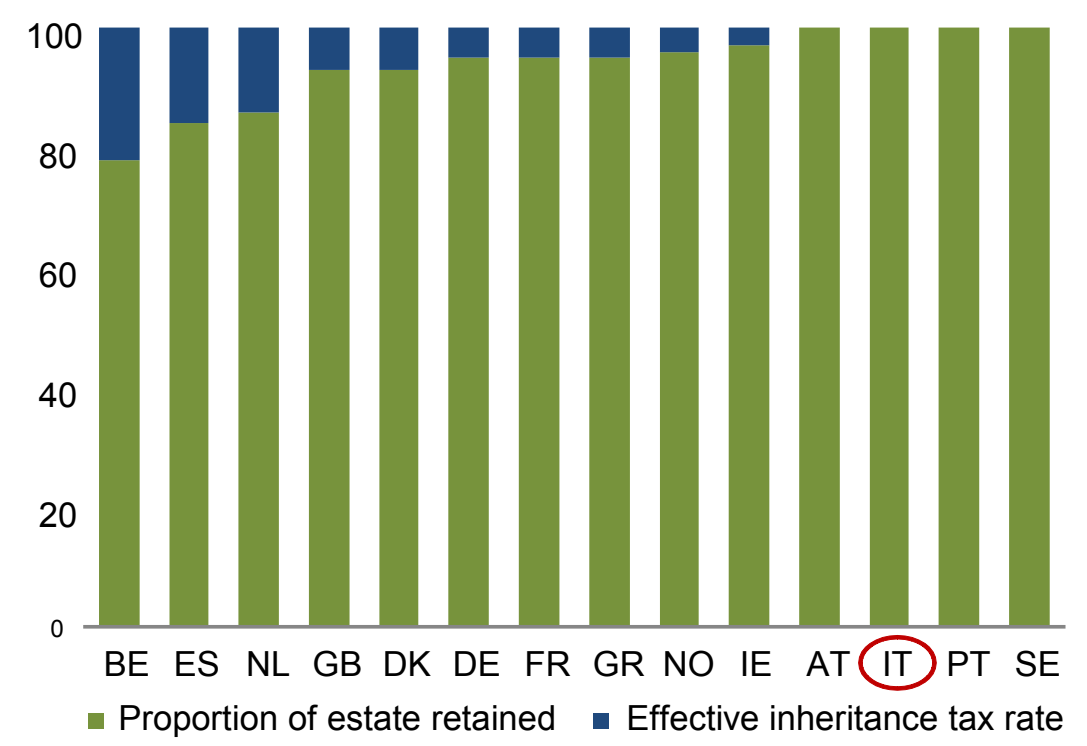

Source: AGN International (2013).

Note: Tax paid on married individuals who died on 01/01/2013, leaving a spouse and two children. Assets owned at death are a house of $€ 600,000$; cash of $€ 1,000,000$; quoted company shares of $€ 300,000$; and unquoted company shares of $€ 700,000$ (total asset value $€ 2,600,000$ ).

The tax is likely to have little impact. The purpose of the inheritance tax is to equalize opportunities and mitigate potential adverse effect of wealth transmission on effort and saving of the donee. The current system likely has little effect of this kind, simply because of the combination of high allowances and low flat rates. First, the allowance for the closest relatives seems particularly high: up to $€ 2$ million can be transferred tax-free, if the estate is owned in equal shares by the parents and is given to their only child. ${ }^{29}$ Only 1 percent of households have net wealth above $€ 2$ million (according to the Bank of Italy 2010 Survey on Household Income and Wealth). Second, the flat rates are low, in particular compared with the PIT rate schedule. From an economic point of view, there is little rationale for taxing far less someone who gets revenue unrelated to work or saving than someone who gets income from his or her own effort. A progressive banding structure may be fairer, and not much more detrimental to work incentives. This could involve a lower rate equal to the lowest PIT rate (23 percent), and a top marginal rate close to the highest rate (43 percent).

The merits of some exemptions are questionable. First, transfers of enterprises or controlling stakes in enterprises to descendants or spouses are exempt from the inheritance and gift tax, so long as the beneficiary continues the business activity for the next 5 years. This protects against the risk that a family business must be sold on death to pay the tax. But there is some evidence

\footnotetext{
${ }^{29}$ On average, there is only one child per family in Italy.
} 
that such retention of SMEs may entrench inefficient management (Bloom, 2006). A better option may be to eliminate this exemption, but allow the tax to be paid in installments, over 5 or 10 years for instance. Second, family homes benefit from a significant reduction of transaction taxes if the donee uses the property as his or her main residence. This may reflect concern that joint occupiers should not have to sell the house on the first death, but can create an incentive to over-invest in homes. ${ }^{30}$ A solution would be to eliminate this relief but allow deferring the tax payment until the subsequent sale of the home (with some lock-in effects as potential drawback). Third, the rationale for exempting government bonds from the inheritance tax but not from the gift tax is unclear.

Capital gains on inheritances are not taxed in many cases. ${ }^{31}$ This relief is sometimes claimed to be warranted on the grounds that taxing capital gains on death is double taxation if the asset is also subject to an inheritance tax. But there are good reasons to tax both (Boadway, and others, 2010). First, the two taxes have different roles. The aim of capital gains tax is to ensure that capital gains are treated like other forms of income; transfer taxes have a different goal. Second, exempting capital gains at death may distort behavior: individuals are encouraged to hold onto assets that have risen in value, and/or buy high yield assets, and convert income into capital gains. ${ }^{32}$ Third, the capital gain exemption comes on top of other reliefs granted to owneroccupied homes. As a result, increases in their value are very lightly taxed in Italy: they are exempt from capital gains tax at sale (as the sale of a primary residence, and that of a secondary home held for more than five years are also exempt from capital gain taxes), and partly at death (due to the capital gain exemption, but also to the fact that the transaction taxes are reduced to a small lump sum fee if the donee uses the property as its primary residence). Only the inheritance tax would capture capital gains, although imperfectly and at a relatively low rate. Fourth, capital gains on securities other than government bonds are taxed only on the share accrued by the heir in the case of inheritance, and on the full amount in the case of a gift.

\footnotetext{
${ }^{30}$ In addition, there is no obligation for the donee to maintain the primary residence for some minimum period: he or she could declare the house as its primary residence to benefit from the tax relief, and sell it a few days later.

${ }^{31}$ The general rule is that capital gains on assets acquired by inheritance are taxed only on the share accrued by the donee, while capital gains on gifts are taxed on the full amount. In practice, there are numerous exceptions to this rule: (1) Buildings and agricultural land acquired by inheritance are fully exempt, that is to say: no tax is paid on the gains accrued by the donor prior to the transfer, and on those accrued by the donee between the transfer and the property sale; (2) For building land acquired by inheritance, only the capital gain accrued by the donee is taxable (3) For gifts of buildings and agricultural land, there is full exemption if more than five years have passed between the purchase of the property by the donor and its sale by the donee; otherwise the capital gains accrued by both the donor and the donee are taxed; (4) In any case, if the donee uses an inherited building as their primary residence, no capital gain tax is due.

${ }^{32}$ This effect is partly mitigated in Italy by the exemption of capital gains on the sale of the primary residence.
} 


\section{Towards a More Comprehensive TaXation of Wealth?}

Like many others, Italy does not levy a comprehensive tax on net wealth. Until recently, NWTs have been in decline: several European countries repealed an NWT in the last 20 years, including Austria, Denmark, Finland, Germany, the Netherlands, and Sweden. Within Europe, only France, Iceland, Norway, Spain, and Switzerland still have a recurrent NWT. Interestingly counter to this trend, however, both Iceland and Spain recently reintroduced wealth taxes as a temporary measure for fiscal consolidation purposes. The top marginal rate of current NWTs is in general less than 2 percent, while revenues are below 1 percent of GDP (except for Luxembourg, where the wealth tax yields 1.5 to 2 percent of GDP per year).

Italy, however, does tax various financial and real assets owned by households and businesses (Table 2 and Box 1). The December 2011 fiscal package brought important changes, particularly the inclusion of primary residences in the property tax and new taxes on luxury goods and on assets held abroad. These taxes on selected forms of wealth yielded about 1.6 percent of GDP in 2012, slightly above the OECD average (1.4 percent of GDP in 2011).

\begin{tabular}{|c|c|c|}
\hline & In billion & In percent of GDP \\
\hline Real estate held domestically & 23.80 & 1.51 \\
\hline Real estate held abroad & 0.01 & 0.00 \\
\hline $\begin{array}{l}\text { Financial assets held } \\
\text { domestically }{ }^{1}\end{array}$ & 0.00 & 0.00 \\
\hline Financial assets held abroad ${ }^{1}$ & 0.01 & 0.00 \\
\hline Financial assets (tax shield) & 0.88 & 0.06 \\
\hline Luxury goods & 0.13 & 0.01 \\
\hline
\end{tabular}

Source: Italian authorities.

${ }^{1}$ Including bank accounts. Negligible in 2012 as banks used tax credits from previous years.

\section{Box 1. Taxes on Asset Holding in Italy}

Individual and businesses are taxed on financial and real assets held domestically. Real estate was taxed at 0.4 percent for the primary residence and 0.76 percent for other properties until 2013 (a new real property tax system is introduced in 2014). Bank accounts are subject to an annual flat fee of $€ 34$ for individuals, and $€ 100$ for businesses. Financial assets (excluding bank accounts) are taxed at 0.2 percent; the financial sector does not pay this tax. Some luxury goods are subject to specific taxes.

Taxes on assets held abroad are only paid by individuals. Real properties held abroad are subject to the basic IMU rates; financial assets held abroad are taxed at 0.2 percent annually, excluding bank accounts held in EU countries or EEA member states that allow information exchange, which are subject to the $€ 34.2$ lump sum fee.

A special tax applies to financial assets (held aboard and domestically) covered by the 'tax shield' program. Amounts repatriated under the 2001 and 2009 foreign asset disclosure schemes and still not disclosed to the tax administration are taxed at 1.35 percent in 2013, and 0.4 percent from 2014 . 
There has been considerable interest in the possibility of introducing a comprehensive wealth tax in Italy, reflecting the public resistance to spending-only austerity; the search for new resources to quickly reduce public debt; an aim of spreading the burden of fiscal adjustment more equally; the difficulty to draw a clear line between capital and labor income; and the significant concentration of wealth in Italy. Net household wealth amounted to $€ 8.6$ trillion at end-2011, about 4.5 times the public debt, and Italy has one of the highest wealth-to-income ratios in advanced economies (about 770 percent of household disposable income in 2011). The richest 10 percent households hold about half of total net wealth, while income inequality in Italy is above the OECD average.

The current set of wealth taxes is likely to have a modest redistributive impact. Excluding the property tax (which serves a different purpose), these taxes raise relatively little revenue: only 0.1 percent of GDP in 2012. In addition, wealth taxes bear essentially on real property, which constitutes the main asset of the middle class (Table 3). By contrast, the top 10 percent wealthiest households keep almost one-fifth of their gross wealth in financial securities and business equity, which are subject to a lower taxation. ${ }^{33}$

Table 3. Composition of Italian Household Wealth per Net Wealth Decile ${ }^{1}$

\begin{tabular}{ccccccccc}
\hline & \multicolumn{3}{c}{ Real Assets } & & \multicolumn{4}{c}{ Financial Assets } \\
\cline { 2 - 3 } Decile & Real Estate & $\begin{array}{c}\text { Business } \\
\text { Equity }\end{array}$ & Valuables & & Deposits & $\begin{array}{c}\text { Government } \\
\text { Securities }\end{array}$ & $\begin{array}{c}\text { Other } \\
\text { Securities }\end{array}$ & $\begin{array}{c}\text { Trade } \\
\text { Credit }^{2}\end{array}$ \\
\hline 1 & 3 & 2 & 60 & & 33 & 0 & 0 & 1 \\
2 & 2 & 1 & 37 & & 59 & 0 & 0 & 0 \\
3 & 32 & 7 & 14 & & 40 & 3 & 4 & 1 \\
4 & 79 & 3 & 4 & & 11 & 1 & 2 & 0 \\
5 & 87 & 3 & 2 & & 6 & 0 & 1 & 0 \\
6 & 90 & 2 & 1 & & 5 & 1 & 1 & 0 \\
7 & 89 & 2 & 2 & & 5 & 1 & 1 & 0 \\
8 & 87 & 3 & 1 & & 5 & 1 & 3 & 0 \\
9 & 87 & 3 & 1 & & 5 & 1 & 3 & 0 \\
10 & 78 & 10 & 1 & & 4 & 1 & 5 & 1 \\
\hline
\end{tabular}

Source: 2010 Survey on Household Income and Wealth (BOI), and staff estimates. Reading: Real estate accounts for 78 percent of net wealth of the top 10 percent richest households.

${ }_{1}^{1}$ As a share of total (real+financial) assets. Averages over the weighted sample of households.

${ }^{2}$ Or credit extended to other households.

\footnotetext{
${ }^{33}$ Looking at Table 3, it is striking and perhaps surprising that the highest decile hold such a large share of their wealth in non-financial assets. While the data in principle include assets held abroad, it is possible that these are understated; the survey also mentions the possibility that increased risk aversion has led to reduced holding of financial assets since 2000. There are few internationally comparable data, but the top decile in the U.S. held around 70 percent of their wealth in non-financial assets - not entirely dissimilar to the estimates for Italy (Board of Governors of the Federal Reserve System, 2012).
} 
There may be efficiency advantages in a piecemeal approach to wealth taxation, but this also creates distortions. Real property is much less mobile internationally than financial capital, so that efficiency consideration points to taxing it at a higher rate-as is now the case. But such differential treatment raises other concerns. For instance, the steep increase in property taxation may adversely affect the real estate market. And exemptions or preferential tax treatments open up opportunities for avoidance. For instance, the flat fee on bank accounts may encourage some households to divest low-yield assets and keep their savings in bank accounts. Another issue is that wealth taxes are currently levied on gross assets, generating a bias against leveraging. This may amplify the traditionally high propensity of Italian households to save (although their savings rate has declined significantly since the onset of the financial crisis). To mitigate this bias, financial liabilities should be deducted from the taxpayer's gross wealth.

In principle, a NWT could replace the set of existing taxes, applying a single tax rate to all assets (net of liabilities) with a high allowance (possibly with a progressive rate schedule). This would be in addition to the IMU, as their objectives are not similar: the property tax is a benefit tax financing local government services, while the NWT aims at equalizing opportunities, and should be assigned to the central government. A NWT could also complement the capital income tax, if the latter is constrained by policy design - for example, by the commitment to a low flat rate under the DIT system. But there would also be difficulties. It is often argued that a NWT has a higher cost of administration and a higher compliance cost; cost and complexity were important factors behind the repeal of the NWT in several European countries. This argument has, however, somewhat less force in Italy, where taxes on financial and real assets already exist: the shift to a NWT would probably not require a dramatic change in revenue administration, apart from the need to collect information on financial liabilities. Another difficulty is the need to define the appropriate taxable unit of the NWT. ${ }^{34}$ Boadway and others (2010) discuss this issue in the context of the tax reform in England, where husband and wife are also treated as separate units. The system should be designed to minimize incentives to split wealth among family members, for instance by giving households the option to file a joint declaration with specific rates and allowances.

Probably most important, a NWT could significantly discourage capital accumulation. Capital taxation is already very high in Italy by European standards (Figure 1). The layering of the NWT on top of the existing capital income tax could indeed result in high effective marginal rates, particularly at lower real rates of return and at higher inflation rates. ${ }^{35}$ For instance, for an

\footnotetext{
${ }^{34}$ Currently, the taxable unit is the individual in Italy.

${ }^{35}$ Suppose that an asset of value $A$ is subject to a wealth tax at rate $T$ and generates a nominal rate of return of $i=r+\pi$ (where $r$ is the real rate of return and $\pi$ the inflation rate) that is taxed at rate $t$. Total tax paid is then $T A+t(r+\pi) A=\left[t+\left(\frac{T}{r}\right)+\left(\frac{t \pi}{r}\right)\right] r A$, so that the effective tax rate on real returns is: $\tau \equiv t+(T / r)+(t \pi / r)$.
} With zero inflation, $\tau \equiv t+(T / i)$. 
investor earning a 5 percent real return on assets, a 1 percent NWT effectively doubles the current 20 percent capital income tax to 40 percent; in the presence of 2 percent inflation, the tax on the real return would rise to 67 percent in the short term (if inflation is not anticipated, and the pre-tax real rate of return declines) and 48 percent in the medium term (once nominal pre-tax rates of return have adjusted). ${ }^{36}$ Facing lower returns, investors may shift from savings to consumption, which would negatively affect domestic investment and growth. They may also look for opportunities abroad and expatriate. ${ }^{37}$

\section{CONCLUSIONS}

This paper has reviewed issues and options in the taxation of transactions, inheritances, and wealth. These are closely related to one another, and to wider structural directions of tax reform in Italy.

Considerable progress has been made towards a more neutral capital income tax system but challenges remain. Neutrality in the treatment of capital income has been significantly improved, especially with the introduction of the ACE. This eliminates the tax on the normal return to equity at the level of the business, neutralizing the preferential tax treatment of debt finance. Present tax arrangements, however, are not neutral between different organizational forms. To address this issue, the authorities have proposed to introduce a new business tax unifying the treatment of retained earnings across different types of business. This is a further step toward easing distortions of business decisions on organizational form.

Cadastral values should be brought closer to market values. Property tax assessments are more than 20 years out of date, and relative property prices have diverged widely since then: in some regions, they have increased by 500 percent; in others, by half that. While effective in increasing revenues, recent uniform adjustments to cadastral values and rate hikes have highlighted the system's inequities, even though taxable values remain well below market values. Alignment of cadastral prices with market prices will be an important step to improve fairness in property taxation, and so pave the way for more effective use of this instrument. Tax rate cuts could partially offset increases in taxable value resulting from revaluation, but some of the revenue gains should also be used to reduce transaction taxes tied to immovable property.

There is also scope to strengthen the taxation of wealth in Italy. Doing so could enhance social solidarity, and share more equitably the burden of fiscal consolidation. A first step toward wealth taxation reform could be to reduce significantly taxes on asset transactions. These are quite large

\footnotetext{
${ }^{36}$ With 0 percent inflation and 5 percent real return: $0.4=0.2+0.01 / 0.05$. With 2 percent inflation and 3 percent real return: $0.67=0.2+0.01 / 0.03+0.2 * 0.02 / 0.03$. With 2 percent inflation and 5 percent real return: $0.48=$ $0.2+0.01 / 0.05+0.2 * 0.02 / 0.05$.

${ }^{37}$ In any case, these decisions are driven by multiple factors and not only by taxation.
} 
in Italy, but have little justification beyond administrative simplicity: they distort behavior and hinder the efficient allocation of assets. The inheritance tax is quite well designed, but currently has little redistributive impact because of its relatively low rates and high allowances. Adopting a progressive rate schedule may allow Italy to achieve a more ambitious equalization of opportunities. In the medium term, a move toward a more comprehensive taxation of wealth would mean substituting a single NWT for the set of existing taxes. A piecemeal approach allows differentiating rates across assets according to their degree of mobility, which has efficiency advantages; but this comes at some price in terms of equity, and can create its own distortions across types of asset (and difficulty in netting out liabilities). 


\section{References}

AGN International, 2013, “Gift \& Inheritance Tax. A European Comparison,” available at http://www.agn-europe.org/tax/index.html.

Andrews, Dan, 2010, "Real House Prices in OECD Countries: The Role of Demand Shocks and Structural and Policy Factors," OECD Economics Department Working Papers, No. 831, OECD Publishing.

Andrews, Dan, Aida Caldera Sánchez, and Åsa Johansson, 2011, "Housing Markets and Structural Policies in OECD Countries," OECD Economics Department Working Papers, No. 836, OECD Publishing.

Arnold, J., B. Brys, C. Heady, Å. Johansson, C. Schwellnus, and L. Vartia, 2011, "Tax Policy for Economic Recovery and Growth, ” Economic Journal, Vol. 121, pp. 5980 .

Becchetti, Leonardo, Massimo Ferrari, and Ugo Trenta, 2013, "The Impact of the French Tobin Tax," CEIS Working Paper No. 266.

Bloom, Nick, 2006, "Inherited Family Firms and Management Practices: The Case for Modernising the UK's Inheritance Tax," CEP Policy Analysis Paper No. 004.

Boadway, Robin, 2004, “The Dual Income Tax System-An Overview,” CESifo DICE Report 3/2004.

Boadway, Robin, Emma Chamberlain, and Carl Emmerson, 2010, "Taxation of Wealth and Wealth Transfers," Chapter prepared for the Report of a Commission on Reforming the Tax System for the 21st Century, Tax Design: the Mirrlees Review, by J. Mirrlees, S. Adam, T. Besley, R. Blundell, S. Bond, R. Chote, M. Gammie, P. Johnson, G. Myles, and J. Poterba (eds), (Oxford: Oxford University Press).

Board of Governors of the Federal Reserve System, 2012, "Changes in U.S. Family Finances from 2007 to 2010: Evidence from the Survey of Consumer Finances," Federal Reserve Bulletin, Vol.88, No. 2, June.

De Mooij, Ruud, 2011, “Tax Biases to Debt Finance: Assessing the Problem, Finding Solutions," IMF Staff Discussion Note 11/11 (Washington: International Monetary Fund).

International Monetary Fund, 2010, A Fair and Substantial Contribution: Final Report for the G20, available at www.imf.org/external/np/g20/pdf/062710b.pdf. ,2012, "Italy: The Delega Fiscale and the Strategic Orientation of Tax Reform," IMF Country Report No. 12/280. 
Klemm, Alexander, 2007, "Allowances for Corporate Equity in Practice," CESifo Economic Studies, Vol. 53, pp. 229-62.

Matheson, Thornton, 2012, "Security Transaction Taxes: Issues and Evidence," International Tax and Public Finance, Issue No. 8.

Mirrlees, James, Stuart Adam, Timothy Besley, Richard Blundell, Stephen Bond, Robert Chote, Malcolm Gammie, Paul Johnson, Gareth Myles and James Poterba, 2011, Tax by Design: the Mirrlees Review, ISBN: 978-0-19-955374-7, Oxford University Press: September 2011.

Oswald, Andrew J., 1996, "A Conjecture on the Explanation for High Unemployment in the Industrialized Nations: Part I," Warwick University Economic Research Paper No. 475 . , 1999, "The Housing Market and Europe's Unemployment: A Non-Technical Paper," Mimeo, University of Warwick.

Thuronyi, Victor (ed.), 1996, Tax Law Design and Drafting, Vol. 1 (Washington: International Monetary Fund).

Van Ommeren, Jos, and Michiel van Leuvensteijn, 2005, "New Evidence of the Effect of Transaction Costs on Residential Mobility," Journal of Regional Science, Vol. 45, pp. 681-702.

Walters, Lawrence, 2011, Land and Property Tax: A Policy Guide (UN-Habitate: Nairobi). 